\title{
INVESTIGATION OF THE INFLUENCE OF THE TEMPERATURE LEVEL ON THE BILATERAL MEAT FRYING PROCESS
}

\author{
Vyacheslav Skrypnyk \\ Department of processes and apparatuses of food productions \\ Higher Educational Establishment of Ukoopspilka «Poltava University of Economics and Trade» \\ 3 Koval str., Poltava, Ukraine, 36014 \\ skrypnyk_v_a@ukr.net \\ Yaroslav Bychkov \\ Department of processes and apparatuses of food productions \\ Higher Educational Establishment of Ukoopspilka «Poltava University of Economics and Trade» \\ 3 Koval str., Poltava, Ukraine, 36014 \\ microvawe@rambler.ru \\ Natalyia Molchanova \\ Department of processes and apparatuses of food productions \\ Higher Educational Establishment of Ukoopspilka «Poltava University of Economics and Trade» \\ 3 Koval str., Poltava, Ukraine, 36014 \\ Andrii Farisieiev \\ Department of processes and apparatuses of food productions \\ Higher Educational Establishment of Ukoopspilka «Poltava University of Economics and Trade» \\ 3 Koval str., Poltava, Ukraine, 36014 \\ fariseeva_g@mail.ru
}

\begin{abstract}
The elaboration and introduction of the new high-energetic and resource effective equipment in the activity of food industrial enterprises, including restaurant economy is an urgent scientific problem. The most important role at that is played by the unit energetic consumption of energetic processes, which decrease allows to receive an economic effect. The rise of the energetic effectiveness of technological processes of fried meat products manufacturing is possible at the expanse of combining traditional and non-traditional (physical and electrophysical) processing methods. The use of combined thermal processing methods allows to raise the effectiveness of heat conduction from heating environments to a product.

The aim of the research was the determination of the frying surfaces temperature at the bilateral heat supply for a value of the mean integral temperature pressure and frying process duration, ready product output and unit energy consumption.

The change of the initial temperature level of the frying process has an essential influence on the mean integral temperature pressure between a frying surface and product surface layer. The temperature decrease of frying surfaces from $423 \mathrm{~K}$ to $393 \mathrm{~K}$ leads to the decrease of the mean integral temperature pressure between a frying surface temperature and product surface one by $4 \mathrm{~K}$ by the nonlinear law, and allows to raise the coefficient of heat conduction through steam layers. It was proved, that the bilateral frying of natural products of meat at the surfaces temperature $393 \mathrm{~K}$ allows to decrease the process duration by $6 \mathrm{~s}$, to raise the ready product output by $3,3 \%$ and to decrease the unit electric energy consumption by $0,023 \mathrm{~kW} \cdot \mathrm{hour} / \mathrm{kg}$ comparing with the bilateral frying at the surfaces temperature $423 \mathrm{~K}$.
\end{abstract}

Keywords: frying at compression; mean integral temperature pressure; temperature level of process; surface layer of product; heat conduction.

\section{Introduction}

Conductive frying is the one of most spread processes of a thermal processing of natural meat products at enterprises of restaurant economy. The necessary condition of receiving a frying product by the conductive way is the permanent keeping of the high-temperature regime (423...473 K). But such cooking regime negatively influences the quality of a ready product, be- 
cause leads to heterocyclic aromatic amines creation and accumulation in it [1], especially by the temperature and duration of the thermal processing [2]. Mutagens content in ready products rises proportionally to the temperature of the thermal processing, and mutagenicity of forcemeat, fried at the temperature $473 \mathrm{~K}$, is almost twice higher than of one, fried at $423 \mathrm{~K}[2,3]$. The process of natural meat products frying is long in time and needs the essential energy consumption. So, the unit energy source consumption decrease, losses of the ready product mass and shortening of the meat bilateral frying duration is an urgent task.

A lot of attention is paid to the question of the improvement of frying products cooking of meat and meat products. The scientists [4] offer to conduct heat to the whole product surface by using a functional close environment. For shortening the processing duration and increasing the ready product output, there was offered the way of meat products frying, that provides the synchronous surface, infra-red and electrocontact heating [5, 6]. In the works [7-9] theoretical aspects of intensification of the process of meat products bilateral frying under the effect of physical and electrophysical methods were considered. The mechanism of heat conduction from frying surfaces to a product at the bilateral frying of meat is considered and theoretically grounded in the works [10, 11]. At the same time the calculation of the coefficient of heat conduction through steam layers was offered. It demonstrated that the determinative influence on the heat conduction coefficient is realized by a value of the mean integral temperature pressure between a frying surface temperature and one of product surface. It was theoretically assumed, that the decrease of the mean integral temperature pressure leads to the increase of the heat conduction coefficient that, in its turn, allows to reduce the frying process duration, to raise the ready product output and to decrease the unit energy consumption.

\section{Materials and Methods}

The study of the process of the bilateral frying of meat was realized using the experimental stand, presented on Fig. 1, 2. This stand included the experimental sample of the apparatus for realizing the process of the bilateral frying of meat, PC, multifunctional meter of electric energy "Energy-9" (country-producer Ukraine) and three digital devices DTR 02 Universal plus (country-producer - Ukraine) with six thermocouples CK-0,5. The regulation of the temperature of the frying surfaces of the apparatus and the measuring of the temperatures of the external layers and within products were realized using the thermocouples.

The materials of the research were portion natural meat products, a cutlet of pork, cooked by the normative documentation [12].

Semi-products were cut of the brisket across fibers with the thickness $0,01 \mathrm{~m}$ (Fig. 3). The meat raw material was bought in the net of shops "Svygyna" (Poltava city, Ukraine). To decrease losses in the ready products mass, the beating procedure was not applied.

The study of the influence of the frying surfaces temperature on the process of the bilateral frying of natural meat products under the effect of physical and electrophysical methods was realized by the decrease of the frying surfaces temperature from $423 \mathrm{~K}$ to $393 \mathrm{~K}$ with the pitch $10 \mathrm{~K}$. The change of the frying surfaces temperature was realized using DTR 02 "Universal plus", inset in the exterior plate of the apparatus. For providing the minimal decrease of the frying surfaces temperature at product loading, the unit surface power of each frying surface was $38 \mathrm{~kW} / \mathrm{m}^{2}$. The excessive pressure on the product was provided near the limit level during the whole frying process $\left(\mathrm{p}_{\text {lim }} \approx 11,5 \mathrm{kPa}\right)$.

The initial mass of the studied sample $\mathrm{G}_{\text {s-p }}$ and the one of ready products $\mathrm{G}_{\text {r.p. }}$ were determined using analytic scales "AXIS AD-600" (country-producer - Poland) with exactness up to $10^{-3} \mathrm{~kg}$. The ready product output $\mathrm{z}$ was determined by the formula (1):

$$
\mathrm{z}=\frac{\mathrm{G}_{\mathrm{s}-\mathrm{p}}}{\mathrm{G}_{\text {r.p. }}} .
$$

The frying process duration was determined from the temperature of cooled meat storage $\mathrm{T}_{\text {in }}=288 \mathrm{~K}$ to the readiness temperature $\mathrm{T}_{\mathrm{c}}=345 \mathrm{~K}$ [13]. The temperature was fixed using the thermocouples, inset in a product. The signal of the thermocouples was fixed by devices DTRT "Uni- 
versal plus" with computer output of information about the temperature on the display. The frying process duration was fixed using the stopwatch "Electronics IT-01" (country producer USSR).

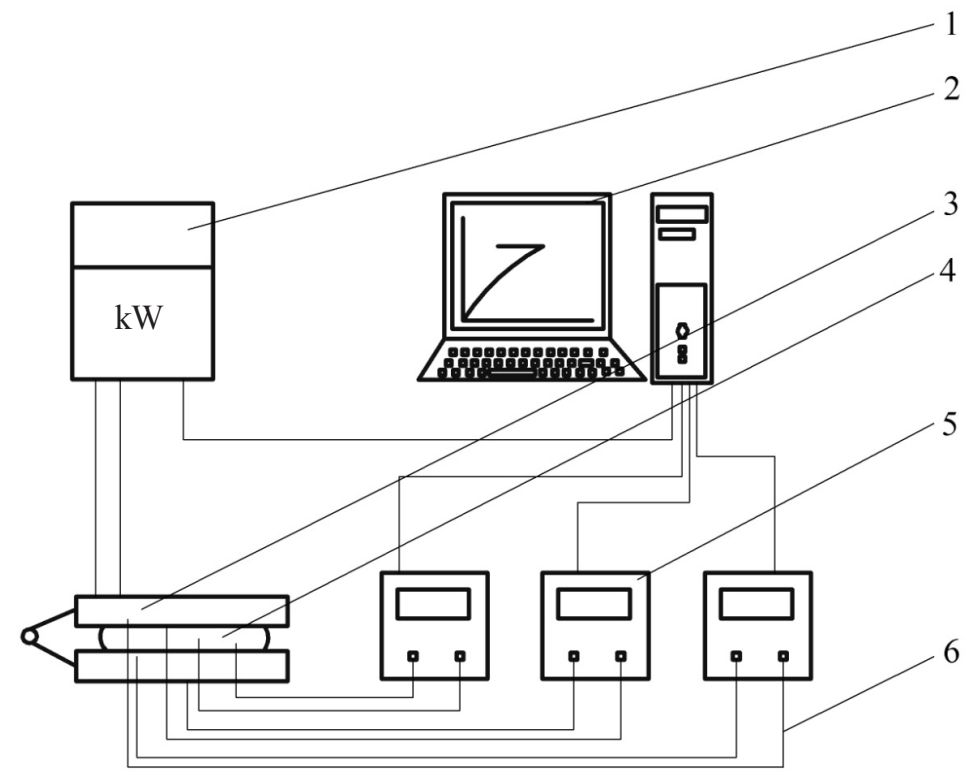

Fig. 1. Scheme of the experimental stand for studying the process of the bilateral frying of meat natural products under the effect of physical and electrophysical methods: 1 - meter of electric

"Energy-9"; 2 - PC; 3 - experimental sample of the apparatus; 4 - experimental sample;

5 - digital device DTR 02 "Universal plus"; 6 - thermocouples CK-0,5

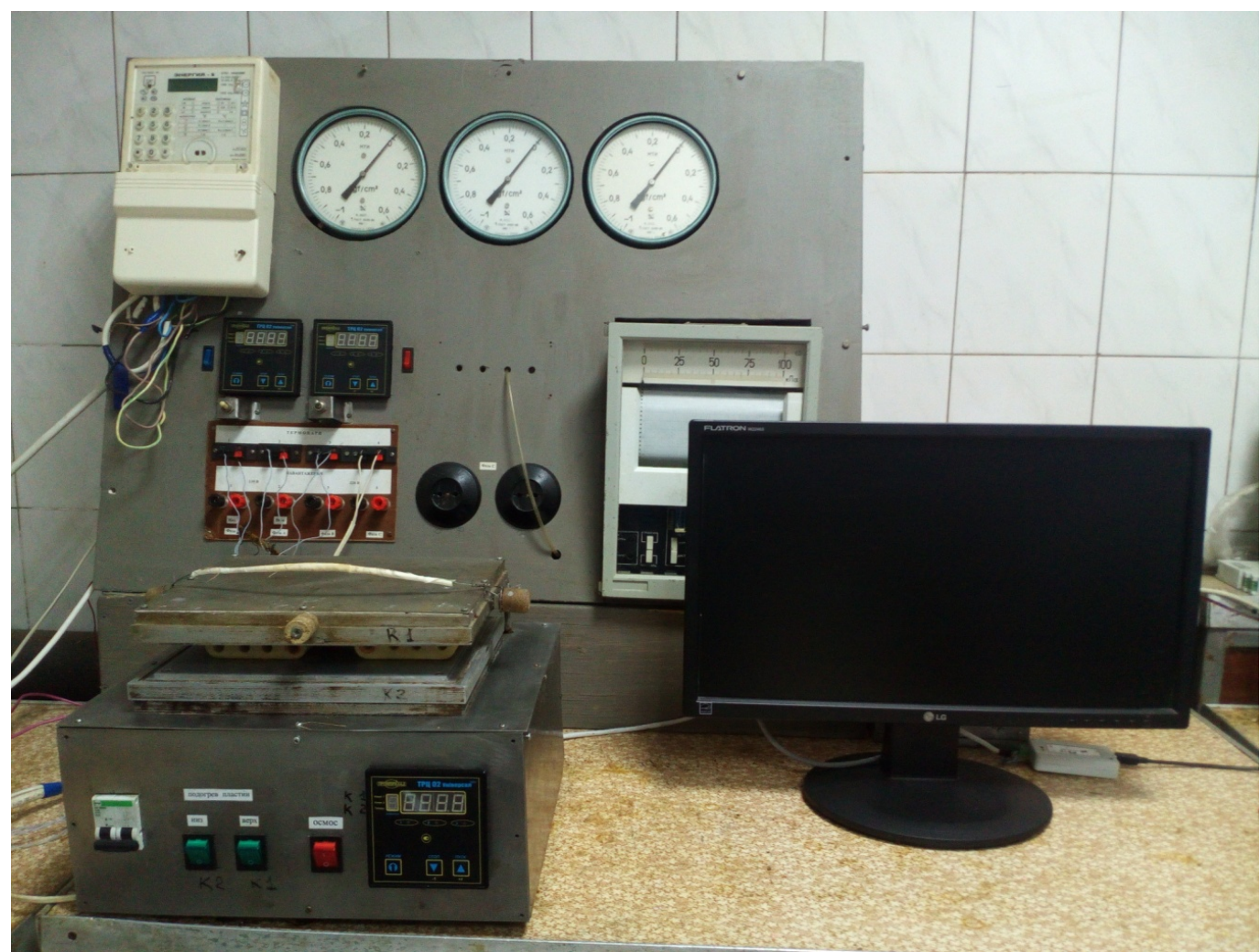

Fig. 2. Experimental stand for studying the process of the bilateral frying of meat natural products 


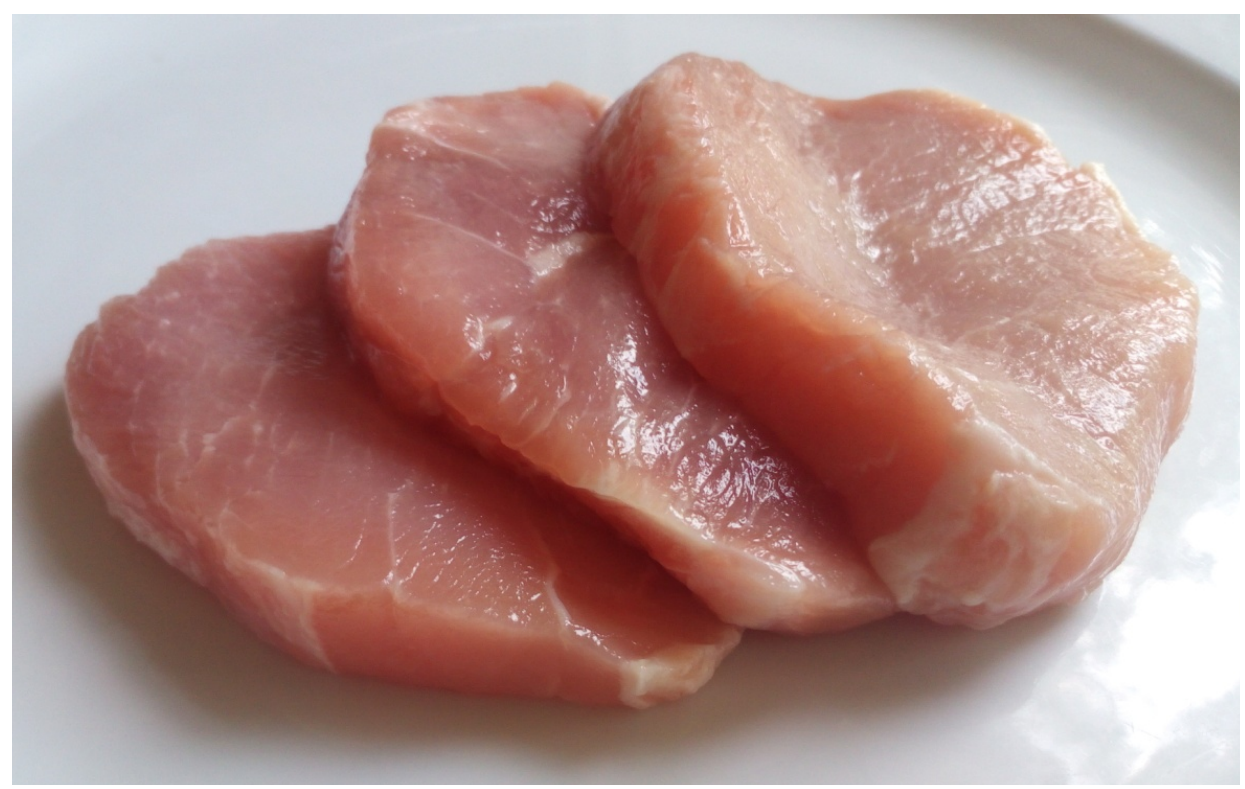

Fig. 3. Natural semi-products of pork

To determine the thermodynamic process duration in capillary menisci using the digital Dictaphone LG, the sound of the frying process was recorded. The Dictaphone was placed on the support at the semi-product height at the distance $0,2 \mathrm{~m}$ from the front of the research-experimental sample of the apparatus. For the further analysis of the sound file Fabfilter Pro.Q2 (Fabfilter software instruments, country producer - USA, Canada) and Spectrum Player (Isualization Software LLC, country producer - USA) programs were used.

The thermodynamic processes duration $\tau_{\mathrm{u}}$ at the bilateral frying of meat was determined by the spectrum of sound frequencies $f, \mathrm{~Hz}$, by the formula (2):

$$
\tau_{\mathrm{L}}=1 / f, \mathrm{~s} .
$$

The known value of the thermodynamic processes duration allows to determine the diameter of meat capillaries and, as a result, to calculate the real coefficient of heat conduction through steam layers.

\section{Results}

As it was demonstrated by the research results, the change of the initial temperature level of frying process has an essential influence on the mean integral temperature pressure between a frying surface and surface product layer. The temperature increase of frying surfaces from $393 \mathrm{~K}$ to $423 \mathrm{~K}$ results in the increase of the mean integral temperature pressure by $4 \mathrm{~K}$, according to the nonlinear law. The frying process duration also increases with the increase of frying surfaces temperature by $6 \mathrm{~s}$. The ready product output also has the non-linear dependence on the frying surfaces temperature at the bilateral frying. The frying surfaces temperature increase from $393 \mathrm{~K}$ to $423 \mathrm{~K}$ leads to the ready product output decrease by $3,3 \%$.

The unit consumption of electric energy also changes depending on the frying surfaces temperature and have the least value at the surfaces temperature $393 \mathrm{~K}$ that corresponds to the least frying process duration and maximal ready product output. The unit consumption of electric energy at the surfaces temperature $423 \mathrm{~K}$ increases by $0,023 \mathrm{~kW} \cdot \mathrm{hour} / \mathrm{kg}$.

\section{Conclusions}

It was established, that the frying surfaces temperature decrease at the bilateral frying of meat allows to decrease the mean integral temperature pressure between the frying surface temperature and the one of the product surface, and to increase the heat conduction coefficient. The use 
of the received results allows to develop modern technological processes of food products thermal processing and to increase the effectiveness of existent ones.

It was proved, that the bilateral frying at the surfaces temperature $393 \mathrm{~K}$ allows to decrease the process duration by $8,6 \%$, to increase the ready product output by $3,3 \%$ and to decrease the unit energy consumption by $20,5 \%$ comparing with the bilateral frying at the surfaces temperature $423 \mathrm{~K}$. The introduction of processes with offered parameters in the activity of restaurant enterprises allows to decrease the energy sources consumption and to receive the economic effect.

\section{References}

[1] Tran, N. L., Salmon, C. P., Knize, M. G., Colvin, M. E. (2002). Experimental and simulation studies of heat flow and heterocyclic amine mutagen/carcinogen formation in pan-fried meat patties. Food and Chemical Toxicology, 40 (5), 673-684. doi: 10.1016/s0278-6915(01)00126-0

[2] Rozantsev, E. G., Bershova, T. M., Dmitriev, M. A., Filatov, S. A., Gavrilenkova, T. V. (2008). Vliyanie termicheskoy obrabotki na soderzhanie mutagenov v myasnyih izdeliyah. Myasnaya industriya, 7, 44-47.

[3] Rozantsev, E. G., Dmitriev, M. A., Bershova, T. M. (2005). Geterotsiklicheskie aminy - rezultat intensivnogo teplovogo vozdeystviya na myaso. Myasnaya industriya, 8, $23-25$.

[4] Cherevko, O. I., Mykhaylov, V. M., Lyashenko, B. V. (2000). Rozrobka prystroyu dlya smazhennya sichenykh vyrobiv (PSSV-0,2) ta doslidzhennya yoho funktsional'nykh mozhlyvostey. Visnyk Kharkivskoho derzhavnoho politekhnichnoho universytetu, 124, 54-60.

[5] Mykhaylov, V. M., Babkina, I. V., Shevchenko, A. O. (2008). Rozrobka kombinovanoho sposobu smazhennya ta bahato-funktsiynoho prystroyu dlya yoho zdiysnennya. Prohresyvni tekhnika ta tekhnolohiyi kharchovykh vyrobnytstv restorannoho hospodarstva i torhivli, 2 (8), 202-209.

[6] Cherevko, O. I., Mykhaylov, V. M., Shevchenko, A. O., Babkina, I. V., Karpenko, L. K. (2011). Pat. No. 58275 UA. Kombinovanyi sposib teplovoyi obrobky kharchovykh produktiv. MPK A23L 1/025. No. u201010657; declareted: 03.09.2010; published: 11.04.2011, Bul. No. 7.

[7] Skrypnyk, V. A., Herman, N. V., Molchanova, N. Yu. (2013). Analiticheskoe issledovanie teplomassoobmennyih protsessov pri dvustoronnem zhareni $\mathrm{v}$ funktsionalno zamknutyih emkostyah. Scientific Annals of Moldova, 7, 198-202.

[8] Cherevko, O. I., Skrypnyk, V. O., Molchanova, N. Yu. (2015). Using physical and electrical methods in conductive meat frying. Technology Audit and Production Reserves, 2 (4 (22)), 75-79. doi: $10.15587 / 2312-8372.2015 .40700$

[9] Skrypnyk, V. (2015). The Theoretical Substantiation of Intensification Process Possibilities of Conductive Frying Meat Natural Products. Ukrainian Journal of Food Science, 3 (2), 361-367.

[10] Cherevko, O. I., Skrypnyk, V. O., Farisieiev, A. G. (2015). Teploperedacha v poverkhnevomu shari miasnykh vyrobiv pry dvostoronnomu zharenni v umovakh stysnennya. Progressive technique and technologies of food production enterprises, catering business and trade, 1 (21), 107-120.

[11] Cherevko, O. I., Skrypnyk, V. O., Molchanova, N. Yu., Farisieiev, A. G. (2015). Researching of heat transfer in the surface layer of the meat products at bilateral frying under the action of electric current. Technology Audit and Production Reserves, 4 ( 4 (24)), 47. doi: 10.15587/2312-8372.2015.47700

[12] Zdobnov, A. I., Tsyiganenko, V. A. (2009). Sbornik retseptur blyud i kulinarnyih izdeliy: Dlya predpriyatiy obschestvennogo pitaniya. Kyiv: OOO «Izdatelstvo Ariy», Moscow: IKTTs «Lada», 680.

[13] Yaremachenko, M. A. (1975). Tehnologicheskiy rezhim i osnovnyie parametryi zhareniya myasa krupnyim kuskom. Obschestvennoe pitanie, 11, 102-104. 